Journal of Social Sciences 6 (1): 113-118, 2010

ISSN 1549-3652

(C) 2010 Science Publications

\title{
Venire Reform-Assessing the State and Federal Efforts to Attain Fair, Cross-Sectional Representation in Jury Pools
}

\author{
${ }^{1}$ Thomas White and ${ }^{2}$ Ellen Baik \\ ${ }^{1}$ Department of Criminal Justice, \\ ${ }^{2}$ Department of Political Science, \\ University of Texas-Pan American, Edinburg, Texas 78539
}

\begin{abstract}
Problem statement: The sixth amendment to the United States Constitution guarantees criminal defendants the right to be tried by an impartial jury of peers and the question of what constitutes an "impartial" jury has spawned constitutional controversies in the last several decades as the population of the United States became more ethnically and racially diverse. The Supreme Court has consistently held that an "impartial" jury is a jury chosen from a venire, or jury pool, fairly representative of the community's demographics and this became known as the fair, cross-section requirement for the venire. Federal and state governments have traditionally relied on voter registration lists as their venire source and scholars have argued that the venire source must expand beyond voter registration lists in order to better represent minority groups and thus to meet the fair, cross-section requirement mandated by the Supreme Court. In this study, we examined whether state and federal governments have expanded their venire sources to attain a more representative venire. Approach: To determine whether the federal and state governments have expanded their venire source lists we compiled federal and state requirements on jury source lists. To obtain federal source lists, we analyzed the most recent court orders specifying jury sources to be used in the districts. To determine states' venire sources, we compiled and analyzed the jury venire statutes of fifty states. Results: Interestingly, we found that states were more proactive in expanding their venire source lists. A majority of federal districts continue to solely rely on voter registration lists as their venire source while a majority of states are supplementing voter registration lists with other lists, such as drivers' license records. Some of the states have completely discarded the usage of voter registration lists as their venire source. Conclusion: Mapping of federal rulings and state statutes reveal that the majority of jurisdictions in the United States continue to primarily rely on the voter registration list as their venire source.
\end{abstract}

Key words: Jury pool, venire, sixth amendment, fair cross-section requirement

\section{INTRODUCTION}

The right to be tried by an impartial jury of peers is considered to be one of the most fundamental rights of criminal defendants in the United States. Notwithstanding, the question of what constitutes an "impartial" jury has spawned constitutional controversies as the population of the United States became more ethnically diverse in the last several decades. At least since the 1940s, the United States Supreme Court has strove to define the meaning of an "impartial" jury and has consistently held that the trial jury itself need not be exactly representative of the jurisdiction's demographics but the pool from which jury was chosen must be fairly representative of the community's demographics (Taylor v. Louisiana, 1975). Most recently in 1990, the Supreme Court reaffirmed its position in the case, Holland v. Illinois (1990), stating that the jury pool, also called the venire, must be fairly representative of the community. In this study, we attempted to determine whether and how the federal and state governments have responded to the Supreme Court's representative jury pool requirement and its significances. We first briefly analyze the relevant Supreme Court decisions; we then examine how the federal and state governments have traditionally obtained their venire source lists and how, if any, they modified their source lists.

The Supreme Court first addressed the issue of systematic exclusion from the jury pool in 1880 in

Corresponding Author: Ellen Baik, Department of Political Science, University of Texas-Pan American, Edinburg, Texas 78539 , 


\section{J. Social Sci., 6 (1): 113-118, 2010}

Strauder v. West Virginia (1980). Because the case was decided before the application of the right to a jury trial to the states in Duncan v. Louisiana (1968), the case was decided on equal protection grounds under the 14th Amendment. In Strauder, a black defendant accused of murder sought to have his trial removed to federal court because West Virginia's law permitted only while males to serve as jurors. The Supreme Court ruled that since the West Virginia Constitution guaranteed the right to a trial by jury the absolute exclusion of blacks from jury service violated the defendant's right to equal protection striking down for the first time a state law that categorically excluded racial minorities from serving as jurors.

Following the 1968 incorporation of the 6th Amendment right to trial by an impartial jury in Duncan, Taylor v. Louisiana (1975) became the first case to address the exclusion of certain segments of the community from the jury selection process. Billy J. Taylor was sentenced to death for aggravated kidnapping by an all male jury selected from a jury pool containing no women even though 53\% of the juryeligible population in the parish were women. Louisiana's law excluded women from jury service unless they affirmatively filed a declaration of their desire to serve. Heavily relying on precedents, the Supreme Court held that the right to an impartial jury under the 6th Amendment entails that it be one drawn from a "fair, cross-section of the community" in which the accused is tried noting that:

The unmistakable import of this Court's opinions, at least since $1940 \ldots$ and not repudiated by intervening decisions, is that the selection of a petit jury from a representative cross section of the community is an essential component of the Sixth Amendment right to a jury trial...We accept the fair-cross-section requirement as fundamental to the jury trial guaranteed by the Sixth Amendment and are convinced that the requirement has a solid foundation (Taylor v. Louisiana, 1975)

The court concluded that the systematic exclusion of $53 \%$ of the jury-eligible population violated the faircross-section requirement of the 6th Amendment and defined for the first time what constitutes an "impartial jury"-a constitutionally impartial jury is a jury chosen from a fair, cross-section of the community. The Court also noted that the actual trial juries chosen need not mirror the community's demographics nor "reflect the various distinctive groups" in the community:
It should also be emphasized that, in holding that petit juries must be drawn from a source fairly representative of the community, we impose no requirement that petit juries actually chosen must mirror the community and reflect the various distinctive groups in the population. Defendants are not entitled to a jury of any particular composition...but the jury wheels, pools of names, panels, or venires from which juries are drawn must not systematically exclude distinctive groups in the community and thereby fail to be reasonably representative thereof (Taylor v. Louisiana, 1975)

Four years later in Duren v. Missouri (1979), the Supreme Court again invalidated a state law that resulted in a systematic exclusion of women from jury service. Missouri statute permitted women to affirmatively choose to exempt themselves from jury service and consequently, women comprised only about $15 \%$ of venire even though more than a half of juryeligible population were women. The Court also created a tripartite test for determining under-representation of minority groups in the jury venire:

In order to establish a prima facie violation of the fair cross-section requirement, the defendant must show (1) that the group alleged to be excluded is a "distinctive" group in the community; (2) that the representation of this group in venires from which juries are selected is not fair and reasonable in relation to the number of such persons in the community and (3) that this underrepresentation is due to systematic exclusion of the group in the jury selection process (Duren v. Missouri, 1979)

A defendant making a claim that the venire does not comply with the fair, cross-sectional representation requirement must show all of three requirements.

The Court's most recent pronouncement came in 1990 in Holland v. Illinois (1990) a case that addressed the racial composition in the trial jury. The prosecution used peremptory strikes to excuse the only two black persons on the venire and Holland, a white man, challenged that he had a right to be tried by a jury composed of a representative, cross-section of the community which cannot be established without a black person in his trial jury. The Court rejected Holland's argument and reaffirmed its holding that the "Sixth amendment requirement of a fair cross section on the 


\section{J. Social Sci., 6(1): 113-118, 2010}

venire is a means of assuring, not a representative jury (which the constitution does not demand), but an impartial one (which it does)" (Holland v. Illinois, 1990). Thus, a trial jury drawn from a source fairly representative of the community meets the 6th guarantee to an impartial jury and the actual composition of the jury need not represent the community's demographic composition.

While the United States Supreme Court has struck down state laws that systematically excluded distinct groups from the jury venire, it was reticent to define how a fair cross-section should be attained or even determined. In fact, the Court on numerous occasions has specifically provided that the states are free to prescribe relevant qualifications and provide reasonable exemptions so long as the resulting jury lists are fairly representative of the community. Consequently, modifying the venire source list, if necessary in attaining a fair cross-section of the community on the venire, was essentially left to the discretion of the federal and state governments.

The jury selection process in the United States legal system occurs via two processes-(1) the initial selection of the pool of qualified citizens from which the resulting jury will be selected and (2) the voir dire or questioning of potential jurors (a) to determine any impermissible bias or prejudice that might justify a party in requesting the court to disqualify a juror for cause and (b) to allow parties to better exercise their peremptory challenges, a process by which each side is allowed to strike a predetermined number of jurors, usually without having to disclose their reasons (Bennett and Hirschorn, 1993). Depending on the number of jurors the jurisdiction utilizes, the first persons not disqualified or stricken will comprise the jury that hears a case. Ours is a jury selection system of attrition rather than one of choice (Bennett and Hirschorn, 1993).

The representative jury requirement is directed at the first stage of the jury selection process-jury pool or venire. Historically, the jury pool was selected from voter registration lists (Fukurai et al., 1991; Knack, 1993; Kairys et al., 1997; Eades, 2001; Diamond, 2003; 2006; Behrens, and Gramling, 2004). Relying on voter registration lists had the desirable effect of weeding out non-US citizens who are ineligible for jury service or voting and it had an added benefit of weeding out convicted felons. Nonetheless, this practice also bore a fair share of disadvantages. The first was that it allegedly discouraged voter registration owing to the prospect of jury service. Knack (1993) found a statistically significant relationship between the failure to register to vote and potential for being called for jury service. The second detriment and by far the more troubling and important problem from a constitutional perspective, is that the jury pool drawn from voter registration lists have not, by in large, been representative of the minority populations of communities (Schattschneider, 1975; Fukurai et al., 1991; Babcock, 1993; Kairys et al., 1997; Diamond, 2003; 2006). Previous studies have shown that the resulting juries exhibited "mildly elitist" qualities and often failed to fairly represent persons of minorities, indigents and other groups which would normally appear in a true cross-section of the community (Fukurai et al., 1991; Diamond, 2003; 2006). In fact, juries have often tended to lilt with a decidedly more upper-class accent (Schattschneider, 1975).

Scholars have argued that such disparities often produced unfavorable verdicts against minorities and other groups not represented in the venire and thus the venire source must expand to include additional sources, e.g. Department of Motor Vehicle records, to better represent these groups and to meet the "fair cross-section" requirement mandated by the Supreme Court (Fukurai et al., 1991; Kairys et al., 1997; Diamond, 2003). The quandary to this argument is that the Supreme Court has never specifically held that the use of voter registration lists as the sole source of jury pools violated the 6th Amendment. Thus, it would be interesting to determine whether state and federal governments have expanded their venire sources.

\section{MATERIALS AND METHODS}

Prior to 1968, the federal courts employed a key man system to select potential jurors (Abramson, 1994; Dooley, 2004). Under this system, jury commissioners "solicited the names of "men of recognized intelligence and probity' from notables or 'key man' of the community" (Abramson, 1994). A federal court survey conducted in 1967 revealed that $60 \%$ of the federal district courts selected their jurors in this manner (Abramson, 1994). Then in 1968, Congress passed the Federal Jury Selection Act (FJSA) declaring that all litigants in federal courts are "entitled to a trial by jury...selected at random from a fair cross section of the community in the district or division wherein the court convenes" (28 USC §1861). That same year, the American Bar Association's (ABA) Project on Standards for Criminal Justice publicly advocated a jury system in which "the names of those persons who may be called for jury service should be selected at random from sources which shall furnish a representative cross-section of the community" (Randall et al., 2008). 


\section{J. Social Sci., 6(1): 113-118, 2010}

The current version of the section of the FJSA, 49 USC $§ 1863(b)(2)$, has been amended four times since 1968 , most recently in 1992 . It now requires each district to draft a written plan for random jury selection, which must specify whether the names of prospective jurors will be derived from voter registration lists and if necessary, to provide other sources of prospective jurors ((a) allows districts to adopt different plans for different divisions or combinations of divisions within the division; (b) allows the District of Massachusetts to utilize the lists of residents compiled pursuant to the state statute in lieu of voter lists), that must be approved by a panel consisting of the judicial council of the circuit and the chief judge of the district (Or the chief judge's designee (49 USC $\S 1863(\mathrm{a}))$ ). Thus, each district is left to its own determinations as to whether to use supplemental sources for the district.

In 1970, the National Conference of Commissioners on Uniform State Laws (NCCUSL) issued the Uniform Jury Selection and Service Act (UJSA) and recommended its enactment by all states. The UJSA is a comprehensive jury statute dealing with topics such as random selection, creation of jury commissions, juror compensation and excuses, to assist states in complying with the federal constitutional requirements (Sobol, 1995). A substantial portion of it was based on the Federal Jury Selection and Service Act of 1968 and recommended states to supplement their venire sources with other lists such as lists of utility customers, property taxpayers, motor vehicle registrations and drivers' licenses (Daughtrey, 1975; Sobol, 1995).

Data: To determine what sources the federal districts are utilizing to compile their jury venire, we analyzed the most recent court orders specifying jury sources to be used in the district as well as other relevant information, e.g., local rules, obtained from each of the 94 federal judicial districts' websites. In a few instances where no jury summon sources were available online, we contacted the corresponding district's jury administrators to obtain the respective information. In order to determine jury pool sources utilized by states we compiled and analyzed the venire statutes of all fifty states obtained through Lexis-Nexis database.

\section{RESULTS AND DISCUSSION}

We found that all federal districts, except Massachusetts who relies on its unique "resident list" for both federal and state jury venires, rely on voter registration sources to some extent and that more than $60 \%$ of the districts rely solely on this source. Those that utilize additional sources were primarily relying on the Department of Motor Vehicles records, e.g., drivers' licenses. The results were surprising given that the federal government has initiated the movement to expand the venire source lists since 1968 with the passage of FJSA and we expected the federal districts to be the ones with expansive source lists. On the contrary, the state governments were the ones who have expanded their source lists.

Because the Supreme Court's decisions did not expound on specific alternative procedures, the statutory changes reflect a diverse interpretation and application of the decisions at the state level. In deciphering sundry statutory terms and format utilized by states, we thought it best to group the statutes into two main groups-states that primarily rely on the voter registration list versus those that do not utilize the voter registration list at all-with several variations within. Also, we found that eighteen states codified the requirement of "fair cross section" in their venire statutes and those states are denoted in bold letters in their respective tables.

Table 1 shows that forty-two states continue to primarily rely on the voter registration list as their venire source. Of these, ten states solely rely on their voter registration list with several permitting supplementation as determined necessary by the state's highest court or at the local level (some states, e.g., Indiana, permit local jury commissioners to supplement the list while others, e.g., Arizona, require the local judge to authorize the supplementation). While the supplementation is not required or is optional for these ten states, the other thirty-two states mandate supplementation by other sources. The most commonly utilized supplemental source is the Department of Motor Vehicles record, e.g., drivers' licenses and stateissue identification cards. Fifteen states require additional supplementation from various sources, e.g., state income tax record, utility rolls, telephone directories and state census records.

Table 2 shows that eight states do not rely on voter registration lists as their venire source. Five states primarily rely on drivers' license record, often supplemented by other sources, e.g., state-issued identification cards. Two states, Massachusetts and Utah, utilized their own unique "resident list" and Alaska utilizes the list of Alaskan fund applicants and a list of volunteers. The results are contrary to what we found in the federal districts. Forty-eight of fifty states permit supplementation by sources other than voter registration lists, though the granting authority varies and is not mandatory in many states and it seemed that states were more willing to expand their venire source list than their federal counterparts. 
Table 1: States that primarily rely on voter registration lists as their venire source

\begin{tabular}{|c|c|c|c|}
\hline VR & $\mathrm{VR}+\mathrm{DL}$ & $\mathrm{VR}+\mathrm{DL}+\mathrm{ID}$ & $\begin{array}{l}\text { VR + DL } \\
+ \text { other sources }\end{array}$ \\
\hline Arizona* & Colorado & Arkansas & Alabama \\
\hline Delaware** & Iowa** & Georgia & California\# \\
\hline Idaho* & Maine* & Illinois & Connecticut \\
\hline Indiana** & Nebraska & Maryland** & Hawaii \\
\hline Louisiana** & North Carolina & Montana & Kansas\# \\
\hline Mississippi & Ohio & New Hampshire & Kentucky \\
\hline Nevada & South Dakota & Oregon* & Missouri**** \\
\hline North Dakota* & & South Carolina & New Jersey\# \\
\hline Pennsylvania $* * * * *$ & & Texas & New Mexico \\
\hline \multirow[t]{6}{*}{ Wyoming** } & & Washington & New York \\
\hline & & & Rhode Island\# \\
\hline & & & Vermont \\
\hline & & & Virginia \\
\hline & & & West Virginia \\
\hline & & & Wisconsin\# \\
\hline
\end{tabular}

Note: *: Judicial discretion on supplementation; **: Local discretion on supplementation; ***: Combination of $2+$ records; $* * * *$ : Supplementation optional; \# :+ID; VR: Voter Registration; DL: Drivers' Licenses; ID: State-issued identification cards; Other sources: Tax records, utility rolls, phone directory, census; States in bold denote the codification of "fair, cross-section" in their statutes

Table 2: States that do not rely on voter registration lists as their venire source

\begin{tabular}{|c|c|c|c|}
\hline $\mathrm{DL}$ & DL+ ID & $\mathrm{DL}+$ tax record & Other sources \\
\hline $\begin{array}{l}\text { Minnesota } \\
\text { Michigan } \\
\text { Oklahoma+ }\end{array}$ & Florida+ & Tennessee & $\begin{array}{l}\text { Alaska+++ } \\
\text { Massachusetts++ } \\
\text { Utah++ }\end{array}$ \\
\hline \multicolumn{4}{|c|}{$\begin{array}{l}\text { Note: +: Volunteers; ++: Resident list; +++: Alaskan fund + } \\
\text { volunteers; DL: Drivers' Licenses; ID: State-issued identification } \\
\text { cards; States in bold denote the codification of "fair, cross-section" } \\
\text { in their statutes }\end{array}$} \\
\hline
\end{tabular}

\section{CONCLUSION}

Mapping of federal rulings and state statutes reveal that the majority of jurisdictions in the United States continue to primarily rely on the voter registration list as their venire source. Yet, forty-eight of fifty permit supplementation by other sources and eight states do not rely on voter registration lists. The most commonly utilized supplemental source is the record from the Department Motor Vehicles and a few states resort to their own unique source lists.

A 2003 report by the American Bar Association's (ABA) Commission on the 21st Century Judiciary concluded "meaningful steps should be taken to ensure that every jury pool represents a fair cross-section of the community from which it is drawn" including expanding source lists, reducing exemptions and alleviating financial burdens that disproportionately impact low income citizens, e.g., reducing the length and frequency of service, providing child care and increasing the level of juror compensation (American Bar Association, 2003). Then in 2005, the ABA's American Jury Project provided in Principle 10 of its 19 principles "that define our fundamental aspirations for the management of the jury system" that "juror source pools should be assembled so as to assure representativeness and inclusiveness" (American Bar Association, 2005). This time, the ABA was more specific recommending that (1) juror source lists be compiled from two or more regularly maintained lists that are updated at least annually and (2) the juror source list and the assembled jury pool should be representative and inclusive of the eligible population such that the percentage of cognizable group members are reasonably proportionate to their incidence in the population (American Bar Association, 2005). Additionally, the United States Supreme Court has recently granted certiorari to a case from Michigan regarding minority representation in the jury and it seems that the Supreme Court may step in to require specific alternative procedures in the future as the United States population become increasingly diverse in ethnicity, age and economic standing.

\section{REFERENCES}

Abramson, J., 1994. We the Jury: The Jury System and the Ideal of Democracy. Basic Books, New York, ISBN: 0674004302, pp: 9-20.

American Bar Association, (ABA), 2003. Justice in jeopardy: Report of the ABA commission on the 21st century judiciary. American Bar Association, pp: 65-67.

American Bar Association, (ABA), 2005. The ABA principles for juries and jury trials. American Bar Association, pp: 1-57. http://www.abanet.org/juryprojectstandards/The_A BA_Principles_for_Juries_and_Jury_Trials.pdf

Babcock, B.A., 1993. Jury Service and Community Representation. In: Verdict: Assessing the Civil Jury System, Robert, E.L. (Ed.). Brookings Institute, Washington DC., ISBN: 0-8157-5282-2, pp: 460-499.

Behrens, M.A. and E.O. Gramling, 2004. Improving the jury system in Kansas: A call for jury patriotism legislation. Kansas J. Law Public Policy, 13: 154-164. http://www.law.ku.edu/publications/journal/pdf/v1 3n2/behrens.pdf

Bennett, C. and R Hirschorn, 1993. Bennett's Guide to Jury Selection and Trial Dynamics in Civil and Criminal Litigation. West Publishing Company, Minnesota, ISBN: 10: 0314022708, pp: 220.

Daughtrey, M.C., 1975. Cross Sectionalism in juryselection procedures after Taylor v. Louisiana. Tennessee Law Rev., 43: 49. http://www.ncjrs.gov/App/Publications/abstract.asp $\mathrm{x} ? \mathrm{ID}=35899$ 
Diamond, S.S., 2003. Truth, justice and the jury. Harvard J. Law Public Policy, 43: 143-155. http://www.law.northwestern.edu/faculty/fulltime/d iamond/papers/HarvardPublicPolicy.pdf

Diamond, S.S., 2006. Essay: Beyond fantasy and nightmare: A portrait of the jury. Buffalo Law Rev., 54: 717-763. http://www.law.northwestern.edu/faculty/fulltime/d iamond/papers/BeyondFantasy.pdf

Dooley, L.G., 2004. The dilution effect: Federalization, fair cross-sections and the concept of community. DePaul Law Rev., 54: 79. http://law.bepress.com/expresso/eps/30

Duncan v. Louisiana, 1968. 391 US145.

Duren v. Missouri, 1979. 439 US 357.

Eades, T.M., 2001. Revisiting the jury system in Texas: A study of the jury pool in Dallas county. South. Methodist Univ. Law Rev., 54: 1813.

Fukurai, H., E.W. Butler and R. Krooth, 1991. Crosssectional jury representation or systematic jury representation? Simple random and cluster sampling strategies to jury selection. J. Crimin. Justice, $\quad 19$ : 31-48. DOI: 10.1016/00472352(91)90081-6

Holland v. Illinois, 1990. 493 US 474.

Kairys, D., J.B. Kadane and J.P. Lehoczky, 1997. Jury representativeness: A mandate for multiple source lists. Calif. Law Rev., 65: 776-827. http://www.jstor.org/stable/3480045

Knack, S., 1993. The voter participation effects of selecting jurors from registration lists. J. Law Econ., 36: 99-114. http://www.jstor.org/stable/725435
Randall, R., J.A. Woods and R.G. Martin, 2008. Racial representativeness of juries: An analysis of source list and administrative effects on the jury pool. Justice Syst. J., 29: 71-84. http://contentdm.ncsconline.org/cgibin/showfile.exe?CISOROOT=/juries\&CISOPTR= 161

Schattschneider, E.E., 1975. The Semisovereign People. Wadsworth Publishing, USA., ISBN: 10: 0030133661, pp: 176.

Sobol, J., 1995. Hardship excuses and occupational exemptions: The impairment of the "fair crosssection of the community. South. Calif. Law Rev., 69: 155.

Strauder v. West Virginia, 1880. 100 US 303.

Taylor v. Louisiana, 1975. 419 US 522.

28 USC $\$ 1861$.

49 USC $\$ 1863$. 